\title{
Gastrin Immunotoxin
}

National Cancer Institute

\section{Source}

National Cancer Institute. Gastrin Immunotoxin. NCI Thesaurus. Code C1692.

An immunotoxin containing an epitope of human gastrin conjug ated to diphtheria toxin, with antineoplastic activity. The gastrin epitope in this vaccine is chemically identical or similar to the endogenous gastrin-17 (G-17), a 17-amino acid peptide hormone that stimulates secretion of gastric acid by the stomach. Diphtheria toxin inhibits protein synthesis via modifying translation elong ation factor 2 (EF-2). Vaccination with this immunotoxin may elicit production of antibodies against gastrinoma cells overexpressing gastrin, in addition to the toxic effects on protein synthesis exerted by the diphtheria toxin moiety. 